\title{
Mis-information and Crisis Communication Management: a case study of a Community Organization Photo Picture during Palu Donggala Disaster
}

\author{
Dyah Permana Erawaty ${ }^{1}$, Dorien Kartikawangi ${ }^{2}$ \\ Department of Communication Studies, Faculty of Social and Political Sciences, \\ University of Indonesia ${ }^{1,2}$ \\ \{seciliamt1@gmail.com,dorien.academic@gmail.com²\}
}

\begin{abstract}
One risk that arise from cyber world is hoax. Although it is Ministry of Communication and Information Technology (Kominfo) responsibility, even the Ministry is not immune from crisis in the communication sector due to cyberspace risks. The purpose of this research is to discuss communication between Kominfo with mass media in an effort to convince the public. Case for this research is complications that occur in the community during a disaster in Palu Donggala, Sulawesi. This study uses a single narrative case study analysis method. The communication concept used in this research is mis-information. The results show that Kominfo needs to develop crisis procedures and protocols (before, during and after the crisis); risks map and crisis management systems need to be developed especially in the field of public relations. Another suggestion is that Kominfo can provide the right of correction to the media and ask the media to share it on their social platforms. The next recommendation is that the research need to measure the level of public trust in Kominfo and the image of Kominfo that is embedded in the community, related to the field of public relations. Press release can also cause disruption of information from a dis-information perspective for certain parties which can trigger a crisis in the organization, even though the intended meaning is limited mis-information. Mis-information can cause moral panic. Collective action manifested in threats through social media is triggered by reasons other than press releases and news. The results show how the spokesperson must act during the communication crisis and have a good sense of risk. Media relations are key when a crisis occurs.
\end{abstract}

Keywords: Crisis Management; Disaster; Mis-Information; Risk; Strategic Communication

\section{Introduction}

Online Social Networks (OSNs) play an important role in how humans communicate and consume information. This important role is because OSNs provide an ideal environment for communication and information acquisition for users who have access to a number of posts 
and articles and share them with others quickly. Unfortunately OSNs are also a mechanism to massively market the diffusion of misinformation [1]. In particular, several reports highlight how OSN is exploited by powerful actors, perhaps even at the state level, targeting individual manipulation through disinformation campaigns [2]. According to Castells, the most important forms of power follow the logic of the power of network making [3]. Dissemination of false information on OSN can cause big problems, it can affect the public in a very worrying way, for example in the way of damaging or changing the image into misinformation potentially changing the election results. Even in a country's crisis situation such as natural disasters, false information can cause panic and chaos. False information that is widely circulated repeatedly through social media can form public opinion that the information is true [4].Social media has been widely used for crisis communication during disasters through the development of mobile technology [5]-[7]. It becomes a matter of course to update events on social media and then enter the main media channels [8]. Information from social media can also be used for decision making regarding evacuation during disasters [9]. The rapid spread of rumors on social media is a critical problem that poses a great risk to navigating emergency situations [10].

The state is present in an effort to provide further prevention of the circulation of misinformation. Related to the internet content control function in Indonesia is within the authority of Sub-Directorate of Internet Content Control Kominfo, that has the task of carrying out the preparation of policy implementation, monitoring, evaluation and reporting in the areas of blocking illegal internet content, infrastructure blocking content, and terminating access to electronic systems [11]. The community can also participate by reporting through various channels such as aduankonten.id. Information related to the hoax was officially announced by Kominfo through a press release by the Public Relations Bureau through the website www.kominfo.go.id. Press release issued by the Ministry will be covered by the news media and then become news content from these media. The results obtained are not always positive, for example when a natural disaster occurs in Donggala Palu. In the midst of the tragedy that befell the people of Palu, Donggala and its surroundings, there are people who take advantage of the situation by spreading information in the wrong context through social media. This information is related to one of the sizable community organizations in Indonesia, the Islamic Defenders Front (FPI). The information was identified by the team and entered into a press release by the Public Relations Bureau which was later posted on an online news media site. Shortly afterwards a negative reaction arose from netizens crisis occurred that had an effect on the reputation and public confidence in Kominfo.

This study aims to determine the crisis communication strategy undertaken by Acting Head of the Information and Communication Bureau of the Ministry of Communication and Information Technology in a crisis situation because of the news coverage in the media based on a press conference conducted by the Office of Kominfo regarding mis-information content in the form of erroneous context on social media from an account of the activities of a community organization in Indonesia when the disaster occurred in Palu Donggala.

A crisis is a perception of unpredictable events that threatens the important expectations of stakeholders and can seriously affect organizational performance and produce negative results [12]. Crisis is stakeholder perception that defines an event as a crisis. Stakeholders are people or groups of people who influence or can influence the organization [13]. According to Loewendick, B. A [14], damage caused by the crisis not only includes financial loss, but includes injury or death to stakeholders, structural or property damage (inside and outside the location), damaging reputation, and environmental damage coombs [12]. Crisis management is designed to ward off or reduce threats by providing recommendations for handling crises 
appropriately. Crisis management represents a set of factors designed to fight the crisis and to reduce losses caused by the crisis. These factors are prevention, preparation, response, and revision [12]. Crisis has an identifiable life cycle, precrisis, crisis event, postcrisis [12]. Understanding the life cycle of a crisis becomes important because it can be used for each stage of the cycle [15]. Communication plays an important role in resolving crises with positive results [16]. Crisis communication becomes the bloodstream throughout crisis management and plays a vital role in all stages of crisis management. Coombs divides crisis response into two categories which have different emphases: form and content [12]. Form is how the response should be presented (fast, consistent, and open), content is what is said [12]. Clear communication is essential in achieving the objectives of the crisis management process to reduce damage, maintain organizational operations, and repair damage to reputation [12].

Situational Crisis Communication Theory (SCCT) is representative of context-oriented research. The main concept underlying it is "reputation", can be said as a public evaluation of the quality of an organization in meeting its public expectations, is an "asset that is intangible and is physically invisible" [17]. Response strategies to crisis situations that can be applied in denial posture are attacking the accuser, denial, scapegoating [12]. For diminished posture, the response strategy is excusing, justification [12]. Response strategies in rebuilding postures are compensation, and apology [12]. SCCT has three variables that can be used by Public Relations practitioners to help identify and determine the actual situation in a crisis that is the basis for determining response strategies to overcome crises [17]: 1) initial crisis responsibility, 2) crisis history, 3) previous organizational reputation (prior relationa reputation).SCCT is used in this study to describe efforts to overcome crises in term precrisis, crisis event, and postcrisis.

Mis-information is sometimes shared by people who believe it is true. Dis-information is false information spread by people who know that information is wrong, willful lies and those who are actively misled by evil actors. Although there are differences, the consequences caused by the information environment and society are similar. Narratives can vary, and their existence can be in other forms of communication, one of which is "wrong context". One reason the term "fake news" doesn't help is because the original content is often seen being circulated back outside its original context. For example, a picture from a certain area in a certain year, circulated again a few years later, shared with the claim that the picture is a photograph of an event elsewhere in a different year [18].

\section{Method}

The research was conducted from 18 to 28 May 2019, and from 5 to 9 August 2019, and using qualitative approach built on the post-positivist paradigm. This research use a case study strategy with a qualitative approach using data collection methods which consist of interviews with Kominfo Public Relations Bureau and the Indonesian Press Council. Case study research focuses on developing in-depth descriptions and analysis of a case (one case) or several cases (several cases) with units of analysis that study the events, programs, activities, or more of an individual [19], which in this study has the uniqueness of a crisis resolution case study caused by the media. The purpose of this study is to determine the processes carried out by the management of Kominfo before, during and after the crisis. For this reason, the research strategy deemed appropriate for this research is a case study. Researchers do not have control over certain events, behaviors, and situations case studies do not require control of certain behaviors and focus on contemporary phenomena in real life contexts [20]. The type of case 
study chosen was a descriptive single-case study with an analysis unit of the Ministry of Communication and Information Technology. This study uses purposive sampling with management sample criteria at the Information and Communication Bureau Public Relations Bureau involved in the crisis in question, and management in the Press Council related to Complaints and Enforcement of Press Ethics. The data is then processed through the coding process here means open coding, axial coding and selective coding which is then followed by interpretation based on the main concept of the object under study as an analysis process.

\section{Result And Discussion}

Based on research results, the beginning of the crisis occurred because of the news in the media. "The beginning was the news on CNN after press release No. 253 / HM / KOMINFO / 10/2018 dated October 2, 2018 issued" said FS as Acting Head of the Ministry of Communication and Information Bureau through an interview. CNN news media on the website www.cnnindonesia.com on Tuesday 2 October 2018 published the news "Communication and Information Call FPI Rapid Motion Photo Helps the Palu Hoaks Earthquake" based on a written statement from Acting Head of the Public Relations Bureau, FS [21]. Starting from a social media account that shows pictures of a number of community organization members helping in the evacuation process with the title "FPI volunteer rapid movement to evacuate victims of the 7.7 earthquake in Palu", then Acting Head of Public Relations Bureau, FS stated that the photo was a fake because it displayed pictures of volunteers in other areas, precisely in the village of Tegal Panjang, Sukabumi, 2015, in a press release.

The mass response emerged shortly, they objected to the press release published in the news because members of community organizations actually helped victims of the disaster in Palu. Social media became lively with protests, and there was even a death threat addressed to the Acting Head of the Public Relations Bureau, which influences the reputation of the Ministry of Communication and Information Technology. Some netizens mocked the community organization but many criticized Kominfo and asked for clarification. FS told me "I received some sympathetic calls, but also out of the thousands of threatening incoming calls, several calls were received directly by me. "

Not all problems become crisis. Challenges and rumors are types of crises that give rise to different interpretations [12]. If the main stakeholders believe that a crisis is happening, then there is indeed a crisis. "because of the threat of personal murder, FS family went to the hotel for four nights until the situation secured. But, the crisis is happening, and because of the threats the ministry office were equipped with metal detector". said FS. Furthermore, "the form of threat posed is a death threat". "For me the crisis is happening not only threaten the reputation of the Ministry of Communication and Information but this crisis is at the level of threatening the safety of life and unsettling the employees of the Ministry of Communication and Information."

The tactical step as a form of crisis response is to carry out Media Relations. Both the Minister of Communication and Information Technology and Acting Head of the Public Relations Bureau contacted CNN Indonesia, "Then, what I did was to contact CNN Indonesia to correct, and they did". This act of responding to the news and asking to be corrected fulfills the right of correction in accordance with Article 5 paragraph 3 of the Press Law. The right of correction is the right of everyone to correct the misinformation provided by the press, both about themselves and/or about others. 
From the results of an interview with RA as head of subsection of Public Complaints of the Secretariat of Press Council of Indonesia, he was said that, indeed the headline of CNN Indonesia's news initially made people misunderstand when reading it". RA further said "The CNN headline was uploaded on Tuesday, October 2, 2018. 12.31 with the title "Communication and Information Call FPI Rapid Motion Helps the Palu Earthquake Only Hoax" contains information from a written statement from Kominfo about some fake news aka. hoax that appeared in the community through social media after the earthquake and tsunami in Palu. One of the information circulating is a photo of FPI volunteers who are helping earthquake victims, according to Kominfo, the photo is a hoax, but the headline of the news "Kominfo Call FPI Fast Motion Helps Palu Earthquake is Just a Hoax" uploaded by $\mathrm{CNN}$ can be interpreted by readers that the assistance activities carried out by FPI are hoax and not true, even though what is meant by the Ministry of Communication and Information Technology is that the photos are not said activities, this has the potential to violate article 1 of the Journalistic Code of Ethics because it is inaccurate. On the same day at 12.43 the CNN editorial team corrected the headline of the news into "Kominfo called the FPI Rapid Motion Photo of the Palu Earthquake is Hoax" in accordance with information provided by Kominfo, and in accordance with Article 4 of the Cyber Media Guidelines, they put note of changes to the title under the news."

Even by doing correction to the news, it does not dampen the threats that received by Public Relations Bureau. FS said "Some of the calls were received directly by me and I explained that what we meant was that the photos were hoax. Then why was the photo, yes, the photo took place in Sukabumi in 2015. Imagine a different time difference place. That is what is called accidental, not dis-information but mis-information. "Even though it has been explained personally, the demand for clarification continues to emerge. "The people who called me demanded clarification. So they want me to explain in full to the press". After being convinced by Acting Head of the Public Relations Bureau to provide an explanation, as a spokesperson, the Minister of Communication and Information provides information to the media. Separately, as a public relations officer, FS compiled a press conference document number 255 / HM / KOMINFO / 10/2018 and invited the media on 4 October 2018 to submit clarification. "Many media are coming," FS said. "Then I publish the official clarification to all of the ministry social media platforms, including ministry official Youtube channel." The crisis ended after the clarification was made and then a new case attracted national attention, an it was the Ratna Sarumpaet case.

New media technology provides new choices for organizations to deal with crises, but this technology can also be a source of crisis for organizations where organizations must respond to the crisis [22]. The crisis caused by the internet is a special case based on technology that stems from the complexity of the system and the interrelationship of components in the system [23]. The cyber crisis involves triggering events that occur in cyberspace, create significant uncertainties, disrupt organizational operations, and can damage organizational relationships or reputation - online and offline [22]. The online crisis is divided into three broad areas: 1) power outages and unplanned service interruptions; 2) dangerous comments, hoaxes or rumors, and 3) direct attacks by detractors [22]. In an effort to prevent the occurrence of cyber risks, ministry controls negative content on the internet.

Regarding the case above, in terms of strategic management, Kominfo has not yet prepared the steps to prepare for a possible crisis. The Risk Management Team from the Ministry of Communication and Information Technology has been formed by the Minister of Communication and Information with a ministerial decree, but the scope of risk assessment is limited to the tasks and functions related to government priority programs in this case 
Nawacita such as the construction of Base Transceiver Station (BTS) infrastructure. In the border regions of the Republic of Indonesia and the Government Public Relations (GPR) program at the Directorate General of Public Communication Information (IKP). The Secretariat General itself has compiled risk maps for three programs that are considered to be very supportive of government programs, namely Education and Training for Management of Change, Implementation of the Standard System for Program Management Systems (SSMP), and Simplification of Regulations. In addition to the fact that risk maps have not been prepared for each program in the Communication and Information unit, it is realized that employee awareness is still low about the importance of preventing crises or preparing mitigation measures. All organizations should prepare to deal with crises by focusing on 1) diagnosing vulnerabilities, 2) assessing the type of crisis, 3) selecting and training crisis teams, 4) selecting and training spokespersons, 5) developing crisis management plans, 6) reviewing communication systems [12].

The actor behind the handling of the crisis is top management the Minister of Communication and Information Technology, who is the spokesperson because he has full authority and responsibility carried out by the Communication and Information personnel and is responsible for the crisis. But FS did good media relations to deal with this crisis. From the field of strategic management, it can be concluded that Kominfo needs to implement risk management, develop crisis protocols before, during and after the crisis. The risk of information disruption is unpredictable and is generally not well understood by people. Determining who the public (suppliers, enablers, limiter) of the organization will be very helpful in preparing for crisis management measures.

The results showed the unit of analysis was in a victim cluster caused by rumors that Kominfo employed hoax spreaders. The source of the crisis in this study is the mass media, which results in low attribution of crisis responsibility with mild reputational threat. Crisis response that is done tactically is clarification as a form of crisis communication. There is no denial response strategy. The SCCT does not explain the consideration of the situation when the mass media is framing, but the crisis in this case is a situation.

\section{Conclusion}

Through the discussion above, it can be concluded several things, Kominfo does not yet have procedures or protocols for handling crises. The preparation of risk maps and other crisis management systems is recognized as being particularly important for the Public Relations Sector. Determination of mitigation measures and personnel that will deal with if the risk occurs is a must. Public mapping such as enablers, barriers, suppliers, has also not been established, creating loopholes for improvement. The strength of relations with mass media institutions is very prominent in resolving this case. This must be built because the mass media is still a symbol that is trusted by the people of Indonesia. Carefully made press releases can also cause disruption of information in the dis-information perspective for certain parties which can trigger a crisis in the organization, even though what is meant is limited to misinformation related to the wrong context. Mis-information can trigger moral panic.

\section{References}

[1] Olivia Solon, “Facebook's failure: did fake news and polarized politics get Trump 
elected? | Technology | The Guardian,” November 10, 2016. [Online]. Available: https:/www.theguardian.com/technology/2016/nov/10/facebook-fake-news-electionconspiracy-theories. [Accessed: 18-May-2019].

[2] N. C. and C. C. Matthew Rosenberg, "How Trump Consultants Exploited the Facebook Data of Millions - The New York Times," March 17, 2018. [Online]. Available: https:/www.nytimes.com/2018/03/17/us/politics/cambridge-analytica-trumpcampaign.html. [Accessed: 18-May-2019].

[3] M. Castells, “A network theory of power," Int. J. Commun., vol. 5, pp. 773-787, 2011.

[4] C. Juditha, "Interaksi Komunikasi Hoax di Media Sosial serta Antisipasinya," J. Pekommas, vol. 3, no. 1, pp. 31-44, 2018.

[5] A. Gupta, H. Lamba, and P. Kumaraguru, "\$1.00 per RT \#BostonMarathon \#PrayForBoston: Analyzing fake content on twitter," in eCrime Researchers Summit, eCrime, 2013.

[6] B. Kang, T. Hölerer, and J. O’Donovan, "Believe it or not? Analyzing information credibility in microblogs," in Proceedings of the 2015 IEEE/ACM International Conference on Advances in Social Networks Analysis and Mining, ASONAM 2015, 2015.

[7] A. Zubiaga, M. Liakata, R. Procter, G. Wong Sak Hoi, and P. Tolmie, "Analysing how people orient to and spread rumours in social media by looking at conversational threads," PLoS One, 2016.

[8] O. Oh, M. Agrawal, and H. R. Rao, "Information control and terrorism: Tracking the Mumbai terrorist attack through twitter," Inf. Syst. Front., vol. 13, pp. 33-43, 2011.

[9] A. M. Sadri, S. V. Ukkusuri, and H. Gladwin, "The Role of Social Networks and Information Sources on Hurricane Evacuation Decision Making," Nat. Hazards Rev., vol. July, 2017.

[10] B. Wang and J. Zhuang, "Rumor response, debunking response, and decision makings of misinformed Twitter users during disasters," Nat. Hazards, vol. May, no. 11, 2018.

[11] Kominfo, "Peraturan Menteri Komunikasi dan Informatika Republik Indonesia Nomor 6 Tahun 2018 tentang Organisasi dan Tata Kerja Kementerian Komunikasi dan Informatika," vol. 6, no. 2. p. 103, 2018.

[12] W. T. Coombs, Ongoing crisis communication: Planning, managing and responding, second edition, Second edi. United States of America: SAGE Publications, Inc., 2007.

[13] J. M. Bryson, "What to do when Stakeholders matter," Public Manag. Rev., 2004.

[14] L. Barton, Crisis in Organizations II. Cincinnati: South-Western College Pub, 2001.

[15] A. Gonzalez-Herrero and C. B. Pratt, "How to manage a crisis before - or whenever - it hits," Public Relations Q., no. Spring, pp. 25-29, 1995.

[16] R. R. Ulmer, "Effective crisis management through established stakeholder relationships: Malden Mills as a Case Study," Manag. Commun. Q., vol. 14, no. 4, pp. 590-615, 2001.

[17] W. T. Coombs, "Protecting Organization Reputations During a Crisis: The Development and Application of Situational Crisis Communication Theory," Corp. Reput. Rev., vol. 10, no. 3, pp. 163-176, 2007.

[18] C. Ireton and J. Posetti, "Journalism, ' Fake News' \& Disinformation: Handbook for Journalism Education and Training," France, 2018.

[19] J. W. Creswell, Qualitative Inquiry \& Research Design: Choosing Among Five Approaches. 2014.

[20] R. K. Yin, Case study reserach: Desing and method, 5th editio. United States of America: SAGE Publications, inc, 2014. 
[21] Tim, "Kominfo Sebut Foto Gerak Cepat FPI Bantu Gempa Palu Hoaks," 2 Oktober, 2018. [Online]. Available: https://www.cnnindonesia.com/nasional/2018100212075620-334935/kominfo-sebut-foto-gerak-cepat-fpi-bantu-gempa-palu-hoaks. [Accessed: 14-Oct-2019].

[22] R. L. Heath, Handbook of Risk and Crisis Communication. 2014.

[23] C. Perrow, Normal Accidents: Living with High Risk Technologies, Revised ed. Princeton University Press, 2011. 